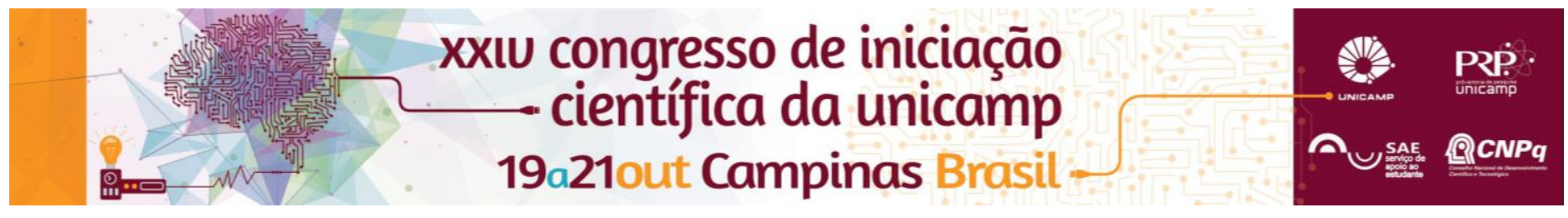

\title{
Comportamento bilíngue do sujeito surdo: Argumentação oral e escrita
}

\author{
Florência N. Secreto*, Profa. Dra. Ivani R. Silva
}

\section{Resumo}

A Língua Brasileira de Sinais (LIBRAS) está em processo de ampliar seu espaço, de modo que com a regulamentação da lei Lei no 10.436, aprovada no dia 24 de abril de 2002, reconhecendo-a como direito do aluno surdo. Com estas mudanças, reconhece-se que o bilinguismo é essencial para que possa existir uma comunicação eficaz entre a cultura surda e ouvinte. É neste universo complexo do mundo surdo que queremos nos aprofundar e observar sua comunicação oral e escrita, verificando quais as marcas argumentativas que aparecem nestes dois contextos.

Palavras-chave: surdez, bilinguimo, argumentação.

\section{Introdução}

Em primeiro lugar, deve-se ressaltar que mesmo com os deslocamentos em relação ao surdo e à surdez, na atualidade, a Língua de Sinais está, ainda, sistematicamente, fora das escolas onde a maioria dos surdos estuda. Esse grupo de alunos não é instruído em LIBRAS e, portanto, tem dificuldades de conversarem com eles ou mesmo explicarem conceitos. Por outro lado, sem intérpretes que façam as traduções das aulas de português para LIBRAS, os alunos surdos ficam à deriva em sala de aula e não conseguem como os alunos ouvintes, participarem das atividades de forma a compreenderem as diferenças entre os gêneros (e outras atividades escolares) e mesmo receber as pistas dos professores em relação aos conteúdos da escola.

Portanto, nosso interesse, neste projeto, será o de compreender o modo como o aluno surdo do nono ano e Ensino Médio argumenta, por escrito ou de forma oral (LIBRAS), verificando quais as marcas e estratégias utilizadas nestes dois contextos.

\section{Resultados e Discussão}

Para tanto, a pesquisa foi submetida ao CEP e aprovada com o número CAAE 48857415.8.0000.5404. Os participantes foram resunidos em três encontros onde foram promovidas discussões a partir de coletâneas sobre assuntos sociais da atualidade. Portanto o objetivo da atividade foi que os alunos assumissem uma posição contra ou a favor do ocorrido e assim pudessem argumentar oralmente e através da escrita em um texto. Foram trabalhados três diferentes assuntos: Maioridade Penal, Greve de Ônibus e Olimpíadas 2016. Antes de realizar a discussão oral e escrever o texto, foi lida a coletânea junto aos alunos para que as ideias fossem explanadas.

\section{Argumentação Oral}

Val (2011) refere que que não há um planejamento para as produções orais. Tal discurso, a saber, é marcado pelo uso de repetições, substituições, seja para enfatizar, clarificar ou corrigir um enunciado anterior, demonstra que 0 planejamento e organização ocorrem simultaneamente (Ochs; 1979 in Francischini; 2002). Podemos notar isto no seguinte excerto da fala de um sujeito surdo não oralizado sobre a Greve de Ônibus (Figura 01):

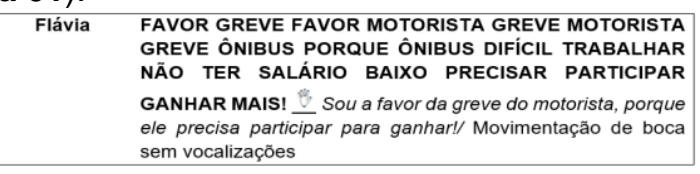

Outra marca presente na argumentação oral e esta também encontrada nos resultados é o discurso que retorna ao já dito, ou seja, o sujeito passa a se apropriar do que já foi dito para construir seu próprio sentido e desta maneira apropriar-se de uma posição própria e empírica (Renzo; 2013).

\section{Argumentação Escrita}

A escrita é produção que requer planejamento, já que é uma atividade consciente e muito pouco automatizada (Cooper \& Matsuhashi; 1983 in Val; 2001). Em nossa análise encontramos achados que evidenciam 0 apagamento de termos importantes para a argumentação, como explicitar "ser a favor de ALGO" ou "ser contra ALGO". Pelo assunto ter sido tratado antes da produção de texto, entende-se que as alunas escreveram a redação como uma extensão do que foi discutido, como a seguir:

"Bom eu sou a favor, porque tem jovens que aprendeu com a família porque a família faz coisa errado (...)" [Lúcia (surda oralizada)/ Assunto: Maioridade Penal]

Também nota-se o retorno ao tom oral através do uso da palavra "bom", tom este que também evidenciou-se em outras redações de outros alunos. Este tom oral utilizado por sujeitos surdos não oralizados trouxe a luz marcas que ressaltam a estrutura da LIBRAS. Exemplo este é trazido no seguinte excerto sobre a Greve de Ônibus (Figura 02). A tradução de LIBRAS para o português está indicada pela figura da mão:

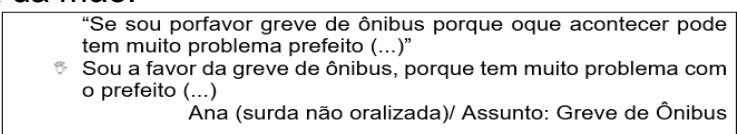

\section{Conclusões}

Notamos que a argumentação só se dá a partir do contexto e também como LIBRAS e/ou Português Oral, registram verdadeiras e significativas marcas no discurso escrito.

\section{Agradecimentos}

Agradeço à minha orientadora Profa. Dra. Ivani Rodrigues Silva por todo apoio e ensinamentos e ao PIBIC pelo fomento para realização desta pesuisa.

FRANCISCHINI, R. ; Construção do texto escrito: mecanismos de referenciação anafórica em narrativas produzidas por crianças. In: Guillermo Soto. (Org.). Discurso para el cambio. Santiago do Chile: La Editorial Universitaria Virtual de la Facultad de Filosofía y Humanidades, v. 1, p. 01-09, 2002.

RENZO, A. M. Repetição, história e efeitos de argumentação na escrita da criança. Nonada Letras em Revista. v 2- n 21- 2013

VAL, M. G. C. O desenvolvimento do conhecimento lingüístico-discursivo: o que se aprende quando se aprende a escrever?. Veredas (UFJF. Impresso), Juiz de Fora, v. 5, n.1, p. 83-104 2001. 